\title{
Effects of pentachlorophenol on the reproduction of Japanese medaka (Oryzias latipes)
}

\author{
Jinmiao Zha ${ }^{\mathrm{a}}$, Zijian Wang ${ }^{\mathrm{a}, *}$, Daniel Schlenk ${ }^{\mathrm{b}}$ \\ a State Key Laboratory of Environmental Aquatic Chemistry, Research Center for Eco-Environmental Sciences, \\ Chinese Academy of Sciences, P. O. Box 2871, Beijing 100085, PR China \\ ${ }^{\mathrm{b}}$ Department of Environmental Sciences, University of California, Riverside, USA
}

Received 16 December 2005; received in revised form 17 February 2006; accepted 17 February 2006

\begin{abstract}
Pentachlorophenol (PCP) is widely used to control termites and protect wood from fungal-rot and wood-boring insects, and is often detected in the aquatic environment. Few studies have evaluated PCP as an environmental endocrine disruptor. In the present work, Japanese medaka (Oryzias latipes) was exposed to PCP for 28 days (F0 generation) with subsequent measurements of vitellogenin (VTG), hepatic 7-ethoxyresorufin- $O$-deethylase (EROD), and reproductive endpoints. Plasma VTG significantly increased in male fish treated with PCP concentrations lower than $200 \mu \mathrm{g} / \mathrm{l}$ and decreased in male and female animals exposed to $200 \mu \mathrm{g} / \mathrm{l}$. Hepatic EROD from female fish increased when PCP exposure concentrations exceeded $20 \mu \mathrm{g} / \mathrm{l}$, but decreased in the $200 \mu \mathrm{g} / \mathrm{l}$ PCP treatment group. Fecundity and mean fertility of female medaka decreased significantly in the second and third week following exposure concentrations greater than $100 \mu \mathrm{g} / \mathrm{l}$, and testis-ova of male medaka was observed at PCP concentrations greater than $50 \mu \mathrm{g} / \mathrm{l}$. Histological lesions of liver and kidney occurred when exposure concentrations exceeded $50 \mu \mathrm{g} / \mathrm{l}$. In F1 generations, the hatching rates and time to hatch of offspring were significantly affected in fish exposed to $200 \mu \mathrm{g} / \mathrm{l}$. These results indicated that PCP exposure caused responses consistent with estrogen and aryl hydrocarbon receptor activation as well as reproductive impairment at environmentally relevant concentrations.
\end{abstract}

(C) 2006 Published by Elsevier Ireland Ltd.

Keywords: Pentachlorophenol; Japanese medaka (Oryzias latipes); EROD; Vitellogenin; Reproduction impairment

\section{Introduction}

Pentachlorophenol (PCP) has been used extensively as a general biocide to control termites and protect wood from fungal-rot and wood-boring insects [1]. In China, PCP and its salts were used principally as a molluscide to control snailborne schistosomiasis as well as a wood

\footnotetext{
* Corresponding author at: State Key Laboratory of Environmental Aquatic Chemistry, Research Center for Eco-Environmental Sciences, Shuangqing Road 18, Haidian District, Beijing 100085, PR China. Tel.: +86106284 9140; fax: +861062923543.

E-mail address: wangzj@ rcees.ac.cn (Z. Wang).
}

preservative [2]. It was also used extensively in aquaculture as a pond-cleaning reagent to control Ampullaria gigas, a winkle introduced into China in 1980s [2]. PCP was banned in China as a pesticide in 1997. However, PCP is still utilized as wood preservative [2].

Other sources of environmental input include paper mill effluent. Thakur et al. [1] reported that bleached paper pulp mill effluent contained large amounts of chlorinated phenols, including PCP. While elevated PCP concentrations can be found in groundwater $(3-23 \mu \mathrm{g} / \mathrm{l})$ and surface water $(0.07-31.9 \mu \mathrm{g} / \mathrm{l})$ within wood-treatment areas in the Unite States, the PCP level of surface waters is usually in the range of $0.1-1.0 \mu \mathrm{g} / \mathrm{l}$, with maximum 
values of up to $11 \mu \mathrm{g} / \mathrm{l}$ [3]. However, PCP concentrations in the $\mathrm{mg} / \mathrm{l}$ range can be encountered near industrial discharges [3]. In China, Zheng et al. [2] reported concentrations of PCP in Tongting Lake ranging from 0.005 to $103.7 \mu \mathrm{g} / \mathrm{l}$, due to its application in the control of snailborne schistosomiasis.

Because of its relatively high hydrophobicity and environmental persistence, PCP is readily bioaccumulated [4]. PCP acts primarily by uncoupling oxidative phosphorylation in the mitochondria [5] and has been listed as a priority pollutant by the United States Environmental Protection Agency (USEPA) because of its toxicity and widespread distribution in the environment [6]. The toxicity of PCP to aquatic organisms such as fish is relatively high, with the $\mathrm{LC}_{50}$ values for goldfish (Carassius auratus) being $0.349 \mathrm{mg} / \mathrm{l}$ after $2.5 \mathrm{~h}$ of exposure [7].

The mechanisms surrounding PCP toxicity have indicated potential Aryl hydrocarbon receptor (AhR) and estrogen receptor activation. For example, PCP was shown to be a partial agonist toward estrogen in the cellular proliferation of MCF-7 cells [8]. However contrasting studies also indicated PCP to be anti-estrogenic by the yeast two-hybrid assay [9]. The potential for PCP to disrupt reproductive function in fish has not been well documented.

Japanese medaka (Oryzias latipes) is an excellent fish model for evaluating the effects of endocrine disrupting chemicals and reproductive toxicants $[10,12]$. The eggs are relatively large with clear chorions which allow internal evaluation of hatching success and development [12]. In the current study, we used Japanese medaka to investigate the reproductive effects of PCP on fish. In addition, we measured histological metrics in gonads, liver and kidney. Biochemical endpoints included measurements of plasma vitellogenin (VTG), and hepatic 7ethoxyresorufin- $O$-deethylase (EROD) following treatment with PCP. The purpose of the study was to determine whether linkages existed between AhR and/or estrogen receptor responses, histopathology and reproductive impairment in fish treated with environmentally relevant concentrations of PCP.

\section{Materials and methods}

\subsection{Test chemical}

PCP (99\% purity) was purchased from Aldrich Chem. Co. (USA). To prepare the stock solution, it was diluted in HPLC-grade acetone and then mixed with distilled water to $1 \mathrm{mg} / \mathrm{l}$. The final acetone concentration in the water was less than $0.01 \%$. To obtain the final exposure concentration, the appropriate amount of the stock solution of PCP was added to the aquarium water via a combination of polytetrafluorethylene (PFTE) and isoversinic tubes (Abimed, Langenfeld, Germany).

\subsection{Test fish}

Japanese medaka (d-rR) was kindly provided by the Laboratory of Freshwater Fish from the Bioscience Center of Nagoya University, in Japan. The brood stock has been maintained in our laboratory for more than 4 years. Japanese medaka were maintained in dechlorinated tap water (using an actived carbon filter) at a constant temperature $\left(25 \pm 2{ }^{\circ} \mathrm{C}\right)$, with a photoperiod of $16: 8 \mathrm{~h}$ (light:dark). The brood stock was fed newly hatched brine shrimp (Artemia nauplii) in the morning and flake food (Trea, Germany) in the afternoon. Medaka fry was fed newly hatched brine shrimp (A. nauplii) twice a day.

\subsection{Exposure and experimental set-up}

Sexually mature medaka (O. latipes: about 5 months old) were the offspring from a batch of brood stock. The body weights and body lengths were $410.12 \pm 50.63 \mathrm{mg}$ and $31.08 \pm 2.11 \mathrm{~mm}$, respectively. Eighty-four breeding pairs were acclimated for 3 weeks in a 10-1 chamber with flow-through dechlorinated tap water $(\mathrm{pH} 7.2-7.6$; hardness $44.0-61.0 \mathrm{mg} \mathrm{CaCO}_{3} / \mathrm{l}$ ) at $25 \pm 1{ }^{\circ} \mathrm{C}$. During the acclimation, the fish were placed under a summer photoperiod (16:8-h light:dark) and fed exclusively with A. nauplii ( $24 \mathrm{~h}$ after hatching) twice a day. During the last week of acclimation, eggs spawned from each pair were collected, counted, and checked for fertility daily. Kondo et al. [4] reported that a no-observedeffect concentration (NOEC) of PCP on medaka for $96 \mathrm{~h}$ was $125 \mu \mathrm{g} / \mathrm{l}$ under flow-through conditions. In present work, Japanese medaka were exposed to PCP at nominal concentrations of 10, 20, 50, 100 and $200 \mu \mathrm{g} / \mathrm{l}$. Four males/females pairs of adult mature medaka were randomly assigned to each of 21 10-1 glass tanks. Three replicates were conducted for each concentration gradient and control. Tap water was passed through an actived carbon filter, aerated and heated to $26^{\circ} \mathrm{C}$ in a reservoir before it was continuously supplied to each aquarium at a rate of $51 / \mathrm{h}$, and flow rates were checked twice daily. The chemical aquaria kept in stock solutions were dosed independently at $60 \mathrm{ml} / \mathrm{h}$ by infusion from a 4-1 glass aspirator, and dosing rates were checked twice daily. Aspirators were refilled every second day. The water and the chemical were mixed and then dispersed to each tank at a rate of $51 / \mathrm{h}$. Exchange of exposure solutions 
of each tank was 12 times per day. The control group received dechlorinated tap water and the solvent control group was exposed only to solvent carrier (acetone $0.1 \mathrm{ml} / \mathrm{l}$ ). The duration of exposure was 28 days. The fish were fed the same diet as during the pre-exposure period under a summer photoperiod (16:8-h light:dark). Eggs spawned from each female fish were carefully collected within a few hours after fertilization. The number of eggs spawned in each treatment group was counted daily, and the ratio of fertilized eggs was calculated. Each embryo was maintained in dechlorinated tap water until hatching, and hatchability and time to hatch was calculated. During the last $24 \mathrm{~h}$ of PCP exposure, all the fertilized eggs from each pair in each treatment group were collected; the hatched larvae were maintained for 60 days in dechlorinated tap water alone and observed for cumulative mortality, total length, body weight, and sex ratio with the appearance of secondary sex characteristics.

\subsection{Measurement of plasma vitellogenin level}

Plasma VTG was measured using a Japanese medaka vitellogenin ELISA kit (TransGenic Inc., Kumamoto, Japan). Fish were netted, anesthetized in $200 \mathrm{ml}$ of dechlorinated tap water containing $200 \mathrm{mg} / \mathrm{l} \mathrm{MS-222} \mathrm{(3-}$ aminobenzoic acid ethyl ester methane sulfonate salt; Sigma, St. Louis, MO, USA, A-5040). Body length and wet body weight were determined. The caudal fin was sectioned and blood collected with a heparinized microcapillary tube. Blood was diluted with ELISA buffer and immediately centrifuged $\left(8000 \times g, 10 \mathrm{~min}, 4^{\circ} \mathrm{C}\right)$ and stored at $-80^{\circ} \mathrm{C}$. The measurement of hepatic VTG was performed according to the manufacturers' procedure. Purified medaka VTG (1, 4, 16, 64 and 256 ng/ml) was used as a standard, and VTG in diluted samples was measured in duplicate. Concentrations of VTG in plasma samples were calculated from the linear part of the logtransformed medaka VTG standard curve. The detection limit of VTG in the present study was $1 \mathrm{ng} / \mathrm{ml}$.

\subsection{Measurement of hepatic EROD}

EROD activity was measured in fish livers. Frozen liver samples were homogenized in Sucrose buffer $0.25 \mathrm{M}(\mathrm{pH} 7.5)$ at a tissue weight/buffer volume ratio of 1:5. They were then centrifuged at $9000 \times g$ (20 min, $4{ }^{\circ} \mathrm{C}$ ) obtaining the postmitochondrial supernatant (PMS) or S9-fraction. A resorufin standard was used to calibrate EROD measurements. The PMS was added to Tris- $\mathrm{HCl}(50 \mathrm{mM}, \mathrm{pH} 7.5)$ and $\mathrm{MgCl}_{2}$ (25 mM). 7-Ethoxyresorufin was added as substrate and NADPH $(10 \mathrm{mM})$ was added to start the reaction. The activity was measured by spectrofluorimetry according to the method of Hahn et al. [13] by a Perkin-Elmer LS-50B spectrofluorimeter, at $590 \mathrm{~nm}$ (emission wavelength) and $535 \mathrm{~nm}$ (excitation wavelength) (5 min, $25^{\circ} \mathrm{C}$ ). EROD activity was calculated as picomoles of resorufin produced/min per $\mathrm{mg}$ protein, using the linear portion of the kinetic curve.

\subsection{Histological analysis}

After complete necropsy of ten male fish per treatment, tissues of gonad, liver and kidney were removed, fixed in buffered formalin (4\%), dehydrated and processed for paraffin wax embedding. The sections were cut at 3-4 $\mu \mathrm{m}$ and stained with hematoxylin and eosin (H\&E). The sections of the paraffin blocks were monitored microscopically.

\subsection{Statistics}

All statistical analyses were performed by using Statistica (version 99) (Sattsoft. Inc., USA). The experimental data, except for those on sex ratios, were checked for homogeneity of variance across treatments by using Levene's test. When the assumptions were met, the data were subjected to one-way analysis of variance followed by Dunnett's multiple comparison tests. When no homogeneity was observed, the nonparametric Kruskal-Wallis test was used followed by the Mann-Whitney $U$-test with Bonferroni's adjustment. The data on sex ratios were assessed by Chi-square analysis. Statistical significances were considered to be significant at $p \leq 0.05$.

\section{Results and discussion}

\subsection{Growth and mortality of adult medaka}

Total length and body weight of male/female medaka significantly decreased relative to the controls $(p<0.05)$ when exposed to $200 \mu \mathrm{g} / \mathrm{l}$ PCP for 28days (Table 1). In addition, total length of females exposed to $100 \mu \mathrm{g} / \mathrm{l} \mathrm{PCP}$ was significantly less than that of the controls $(p<0.05)$ (Table 1). However, there no significant differences in total length and body weight among other treatment groups with the controls after exposure. Some studies have suggested that growth of fish were inhibited when exposure to toxic organ chemicals. For example, Skei et al. [14] have reported that medaka exposure to NP and 4-tert-octylphenol (OP) were decreased in growth. In addition, decreasing of total body length and weight of zebrafish was observed after exposure to 
Table 1

Accumulative death rates, total length, body weight of medaka at end of PCP exposure for 28 days

\begin{tabular}{|c|c|c|c|c|c|}
\hline \multirow[t]{2}{*}{$\mathrm{PCP}$ concentraion ${ }^{\mathrm{a}}(\mu \mathrm{g} / \mathrm{l})$} & \multirow{2}{*}{$\begin{array}{l}\text { Accumulative } \\
\text { death rates }(\%)\end{array}$} & \multicolumn{2}{|c|}{ Total length (mm) } & \multicolumn{2}{|c|}{ Body weight (mg) } \\
\hline & & Male & Female & Male & Female \\
\hline Control & 0 & $36.2 \pm 1.9$ & $39.3 \pm 2.5$ & $537.3 \pm 130.1$ & $841.1 \pm 169.7$ \\
\hline Solvent control & 0 & $36.0 \pm 2.1$ & $39.1 \pm 2.2$ & $523.3 \pm 100.2$ & $791.1 \pm 149.7$ \\
\hline 10 & 4.1 & $35.8 \pm 1.7$ & $39.1 \pm 2.5$ & $529.2 \pm 78.9$ & $796.7 \pm 127.1$ \\
\hline 20 & 0 & $35.3 \pm 2.3$ & $38.1 \pm 2.3$ & $525.5 \pm 163.3$ & $730.9 \pm 164.1$ \\
\hline 50 & 8.2 & $35.1 \pm 2.6$ & $38.5 \pm 1.2$ & $524.4 \pm 115.3$ & $752.8 \pm 52.1$ \\
\hline 100 & 16.7 & $35.1 \pm 1.9$ & $37.3 \pm 3.2^{*}$ & $507.1 \pm 83.14$ & $737.5 \pm 227.9$ \\
\hline 200 & 25 & $34.9 \pm 2.8^{*}$ & $37.6 \pm 3.1^{*}$ & $465.7 \pm 106.2^{*}$ & $655.8 \pm 137.9^{*}$ \\
\hline
\end{tabular}

* Significant differences from the values of the solvent controls or controls at $p<0.05$.

$17 \alpha$-ethynylestradiol (EE2) [15]. Our results indicated that PCP had significant effects on growth inhibition of medaka.

Accumulative death rates of adult mature medaka exposed to 100 and $200 \mu \mathrm{g} / \mathrm{l}$ PCP for 28 days were $16.7 \%$ and $25.0 \%$ (Table 1), respectively. However, there were no significantly difference in accumulative death rates between 10, 20 and $50 \mu \mathrm{g} / \mathrm{l} \mathrm{PCP}$ treatment groups and control groups (Table 1). These results suggested that PCP had chronic toxicity on medaka.

\subsection{Plasma VTG Levels}

Plasma VTG levels were significantly higher for male fish exposed to PCP at 10, 20, 50 and $100 \mu \mathrm{g} / \mathrm{l}$ for 28 days compared to the control group $(p<0.05, p<0.01$, $p<0.01$ and $p<0.05$, respectively) (Fig. 1). Plasma VTG levels of male fish from PCP treatments showed nonlinear dose-response relationship. Additionally, plasma VTG levels of female medaka from 100 and $200 \mu \mathrm{g} / \mathrm{l}$ PCP treatments were significantly less than that of the controls $(p<0.05)$ (Fig. 1).

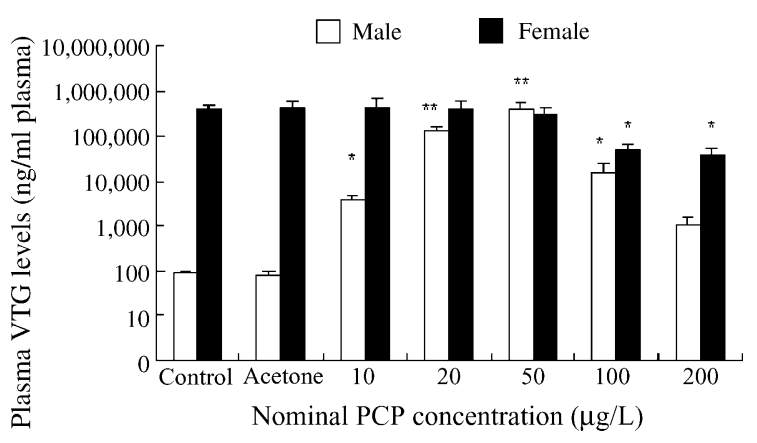

Fig. 1. Plasma vitellogenin (VTG) concentrations of mature medaka after exposure to $\mathrm{PCP}$ for 28 days. * and ** Significant differences from the values of the solvent controls or controls at $p<0.05$ and $p<0.01$, respectively.
Jung et al. [9] reported that PCP had anti-estrogenic activity in the yeast two-hybrid assay. This difference may be due to differences in biotransformation pathways between the in vitro yeast system and the in vivo fish response. Kitamura et al. [16] reported that $p, p^{\prime}$ DDT was metabolized to $p, p^{\prime}$-DDD and $p, p^{\prime}$-DDE by reductive dechlorination and dehydrochlorination, respectively, and only $p, p^{\prime}$-DDE shows estrogenic activity [17]. Recently, a number of studies have reported increase of VTG of medaka when exposed to estrogen or endocrine disrupting chemicals, such as Cd [18], EE2 [19], phytoestrogen such as diet $C$ and organochlorine pesticides such as hexachlorobenzene, $\beta$-benzene hexachloride (BHC), and $\gamma$-BHC in the diet [20]. In addition, increase of VTG of male medaka exposed to sewage effluent has been reported [21]. However, Ankley et al. [22] reported that methyltestosterone (an androgenic chemical) caused significant induction of plasma VTG in both male and female fathead minnows (P. promelas). Ishibashi et al. [12] reported that triclosan (TCS) and its metabolites might be weak androgenic or anti-estrogenic action, but apparently also have the potential to induce hepatic VTG in male medaka.

\subsection{EROD activities in liver microsomes of female medaka}

EROD activities in liver microsomes from female medaka treated with $20,50,100$ and $200 \mu \mathrm{g} / \mathrm{l} \mathrm{PCP}$ exposure for 28 days were significantly higher than that of the control $(p<0.05)$, but not in a linear dosedependent manner (Fig. 2). In previous studies, PCP or its dimmer has proved to be a potent inducer of various cytochrome P-450 in rat and human cells [23-25]. Some studies have suggested that increases in EROD activities which is catalyzed by cytochrome P450 1A (CYP1A) were observed in many species of fish after 


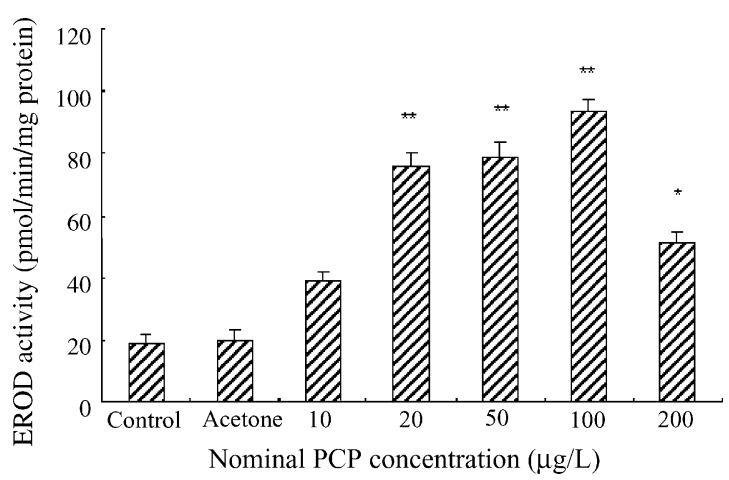

Fig. 2. EROD activities in liver microsomes from female medaka at the end of the exposure period. * and ** Significant differences from the values of the solvent controls or controls at $p<0.05$ and $p<0.01$, respectively.

exposure to PAHs, PCBs, PCDDs and PCDFs [26-28]. The induction of cytochrome P-450 of fish exposed to PCP has not been previously reported. The results from our study indicated PCP caused CYP1A inducer presumably through an AhR mediated pathway. Previous studies have indicated PCP may dimerize leading to the formation of TCDD which is a strong AhR agonist and CYP1A inducer [28]. Whether this occurs within fish is unclear, and deserved further study. These results showed that the dose-dependent manner of EROD induction was comparable to the induction of VTG. Namely, both VTG inducing and EROD activates were simultaneously elevated in PCP-exposed medaka. It is known that estradiol significantly suppresses CYP1A catalytic activity in fish [29]. However, little is known about the effects of xenoestrogens on CYP1A. For example, CYP1A catalytic activity was suppressed when medaka exposed to EE2 [21], while EROD activity were evaluated in adult male channel catfish exposed to methoxychlor [30]. In addition, these similar results were observed in effluent exposure fish [21].

\subsection{Histopathology}

\subsubsection{Gonadal histopathology}

Gonad chrematistics of medaka at the end of the PCP exposure period are shown in Table 2. Testis-ova were observed in male medaka exposed to concentrations higher than $10 \mu \mathrm{g} / \mathrm{l} \mathrm{PCP}$ (Table 2), based on the existence of perincleus-stage occytes within testicular tissues (Fig. 3C). Among treatments, one and three out of twelve male fish $(8.3 \%$ and $25 \%)$ had testis-ova in treatments of 20 and $50 \mu \mathrm{g} / \mathrm{l} \mathrm{PCP}$, and four out of ten male fish (40\%) had testis-ova in the $100 \mu \mathrm{g} / \mathrm{l}$ PCP treatment group. However, in the $200 \mu \mathrm{g} / \mathrm{l} \mathrm{PCP}$ treatment group, only one out of nine male medaka $(11.1 \%)$ had testis-ova. Egimi [31] has reported that prolonged starvation and exposure of non-estrogenic hormones may cause testis-ova in male medaka, but in this study, no testis-ova were observed in male fish from the controls and in the $10 \mu \mathrm{g} / \mathrm{l}$ PCP treatment group.

In previous studies, medaka treated with estrogens and estrogen mimicking compounds caused testis-ova. For example, Kang et al. [32] has reported that medaka exposed to $184 \mu \mathrm{g} / \mathrm{l}$ 4-nonylphenol (NP) had testis-ova in the male fish. In addition, exposure of $o, p^{\prime}$-DDT and organophosphate pesticide (OP) caused induction of testis-ova in male medaka [33,34]. At levels of 10 and $20 \mu \mathrm{g} / \mathrm{l}$ treatments, there was few testis which had occytes, but spermatogenesis (spermatozoa, spermatocytes, and mature spermatids) was unaltered (Fig. 3A). However, in the 100 and $200 \mu \mathrm{g} / \mathrm{l}$ treatments, fewer primary and secondary spermatocytes were observed (Fig. 3B). In the $200 \mu \mathrm{g} / \mathrm{l}$ treatment, six out of nine male medaka (66.6\%) had inhibitive testis (Table 2). For female medaka, we observed ovaries degenerated in the 50, 100 and $200 \mu \mathrm{g} / \mathrm{l} \mathrm{PCP}$ treatment groups (Fig. 3F). In $200 \mu \mathrm{g} / \mathrm{l}$ PCP treatment group, $66.6 \%$ of ovaries from female were atretic (Table 2). An increase in the number of preovulatory atretic follicles also was observed

Table 2

Gonad characteristics of adult mature medaka at the end of the PCP exposure period

\begin{tabular}{|c|c|c|c|c|c|}
\hline \multirow[t]{2}{*}{$\mathrm{PCP}$ concentration $(\mu \mathrm{g} / \mathrm{l})$} & \multicolumn{3}{|c|}{ No. of male medaka } & \multicolumn{2}{|c|}{ No. of female medaka } \\
\hline & Normal testis & Testis-ova & Inhibition testis & Normal ovaries & Degenerate ovaries \\
\hline Control & 12 & 0 & 0 & 12 & 0 \\
\hline Solvent & 12 & 0 & 0 & 12 & 0 \\
\hline 10 & 11 & 0 & 0 & 12 & 0 \\
\hline 20 & 10 & 1 & 1 & 12 & 0 \\
\hline 50 & 7 & 3 & 2 & 11 & 1 \\
\hline 100 & 3 & 4 & 3 & 8 & 2 \\
\hline 200 & 2 & 1 & 6 & 3 & 6 \\
\hline
\end{tabular}



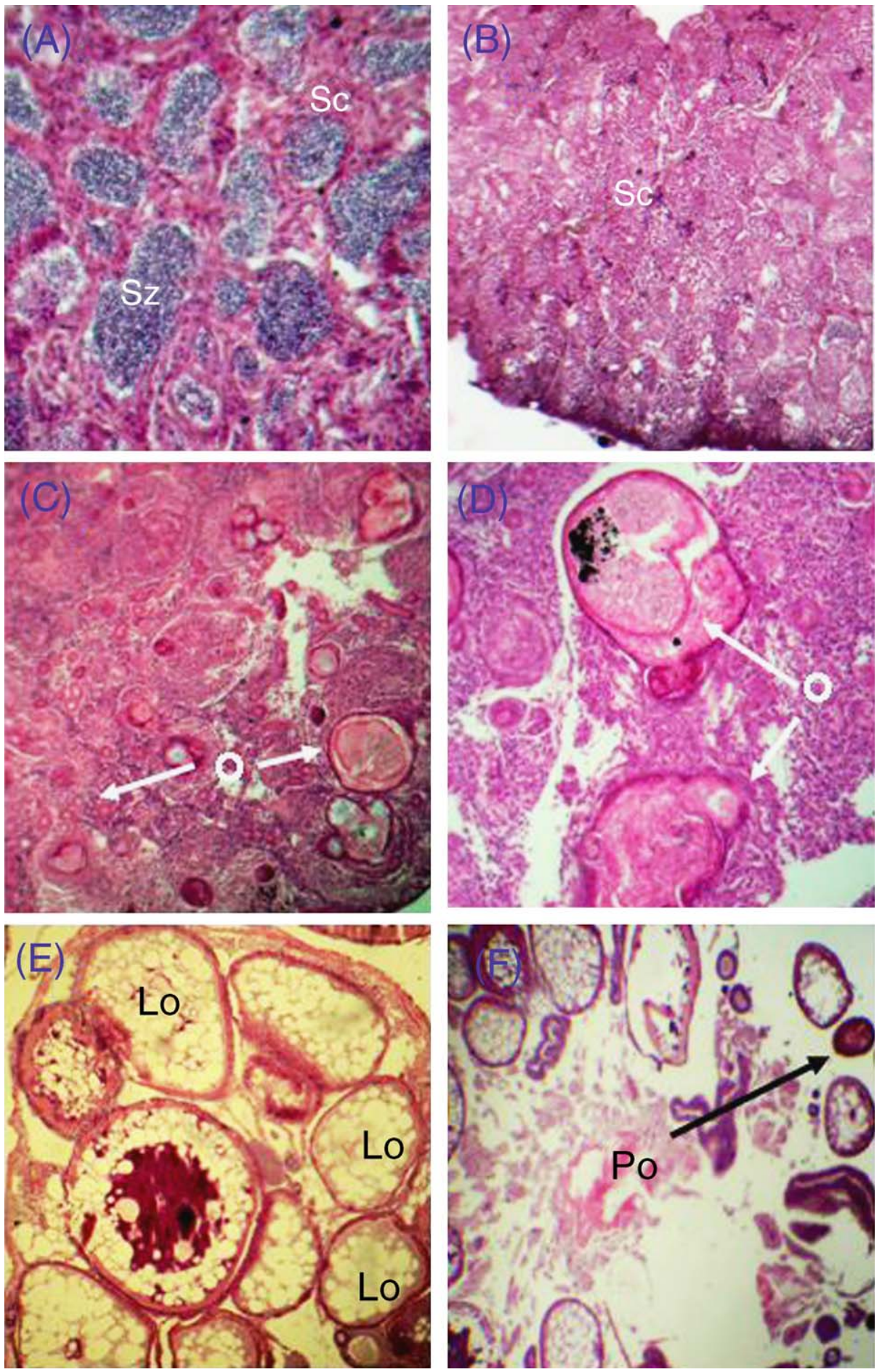

Fig. 3. Histological section of the gonad of mature medaka in PCP exposure experiment, stained with hematoxylin and cosin. (A) Testis of a control male in PCP exposure experiment $(400 \times)$, showing normal spermatogenesis: spermatocytes (Sc) and spermatozoa (Sz). (B) Inhibitive testis of a male from $200 \mu \mathrm{g} / \mathrm{l} \mathrm{PCP}(400 \times)$, spermatocytes (Sc) were shown. (C) Testis-ova of a male exposed to $50 \mu \mathrm{g} / 1 \mathrm{PCP}(400 \times)$, Occytes $(\mathrm{O})$ appear in clusters within the testicular tissue. (D) A more progressed testis-ova exposed to $100 \mu \mathrm{g} / \mathrm{PCP}(400 \times)$, large occytes (O) appear in clusters within the testicular tissue. (E) Ovary of a control female in PCP exposure experiment $(200 \times)$, many late vitellogenic occytes (Lo) are shown. (F) Regressed ovary of a female exposed to $200 \mu \mathrm{g} / \mathrm{l} \mathrm{PCP}(200 \times)$, many previtellogenic occytes (Po) are shown. 
in females fathead minnow exposed to $2-50 \mu \mathrm{g} / \mathrm{l}$ fadrozole for 21-days [35]. Ovaries of medaka injection of 0.5-2.5 ng EE2/egg showed atretic follicles [36].

\subsubsection{Hepatic and renal histopathology}

Tabulation of lesions in hepatic and renal tissue of male medaka at the end of the PCP exposure period was shown in Table 3. Incidences of liver lesions of male medaka from the 50, 100 and $200 \mu \mathrm{g} / \mathrm{l} \mathrm{PCP}$ treatments were $50 \%, 70 \%$ and $87.5 \%$, respectively. Esinophilic material accumulated in liver tissue of fish from the 50 and $100 \mu \mathrm{g} / \mathrm{l} \mathrm{PCP}$ treatments (Fig. 4B). Herman and Kincaid [37] has reported eosinophilic material in tissues after treatment with estrogens indicating its identity was likely to be VTG. Livers of male fish from the 100 and $200 \mu \mathrm{g} / \mathrm{l}$ PCP treatments showed hypertrophy of the hepatocytes and damaged cellar arrays, as well as an enlargement of the cell nuclei accompanied by a distinct reduction of glycogen deposits (Fig. 4C). Similarly, an
Table 3

Number of lesion liver and kidney of the male medaka at the end of the PCP exposure period

\begin{tabular}{llllll}
\hline $\begin{array}{l}\text { PCP } \\
\begin{array}{l}\text { concentration } \\
(\mu \mathrm{g} / \mathrm{l})\end{array}\end{array}$ & \multicolumn{2}{l}{ No. of male medaka } & & \multicolumn{2}{l}{ No. of male medaka } \\
\cline { 2 - 3 } \cline { 5 - 6 } \cline { 5 - 6 } & $\begin{array}{l}\text { Normal } \\
\text { livers }\end{array}$ & $\begin{array}{l}\text { Lesion } \\
\text { livers }\end{array}$ & & $\begin{array}{l}\text { Normal } \\
\text { kidneys }\end{array}$ & $\begin{array}{l}\text { Lesion } \\
\text { kidneys }\end{array}$ \\
\hline Control & 12 & 0 & 12 & 0 \\
Solvent & 12 & 0 & & 12 & 0 \\
10 & 10 & 1 & & 11 & 0 \\
20 & 9 & 3 & & 10 & 2 \\
50 & 6 & 6 & 7 & 5 \\
100 & 3 & 7 & & 5 & 5 \\
200 & 1 & 7 & & 1 & 7 \\
\hline
\end{tabular}

increase in liver cell size has been detected in estradioltreated flounder [38] which may be a consequence of the stimulation of vitellogenin synthesis [39].

In male medaka, normal renal tissue of fish is composed of numerous renal corpuscles with well-developed
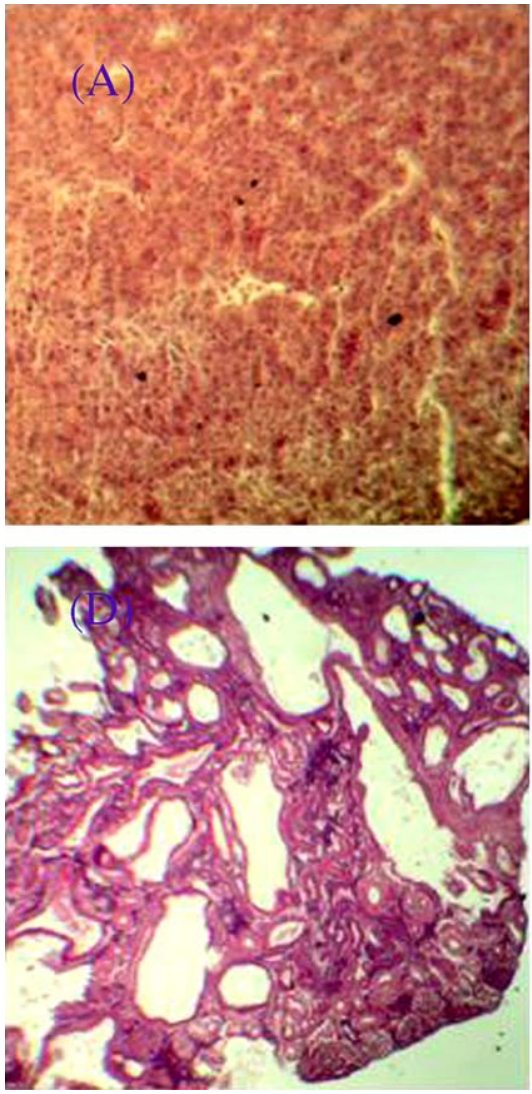
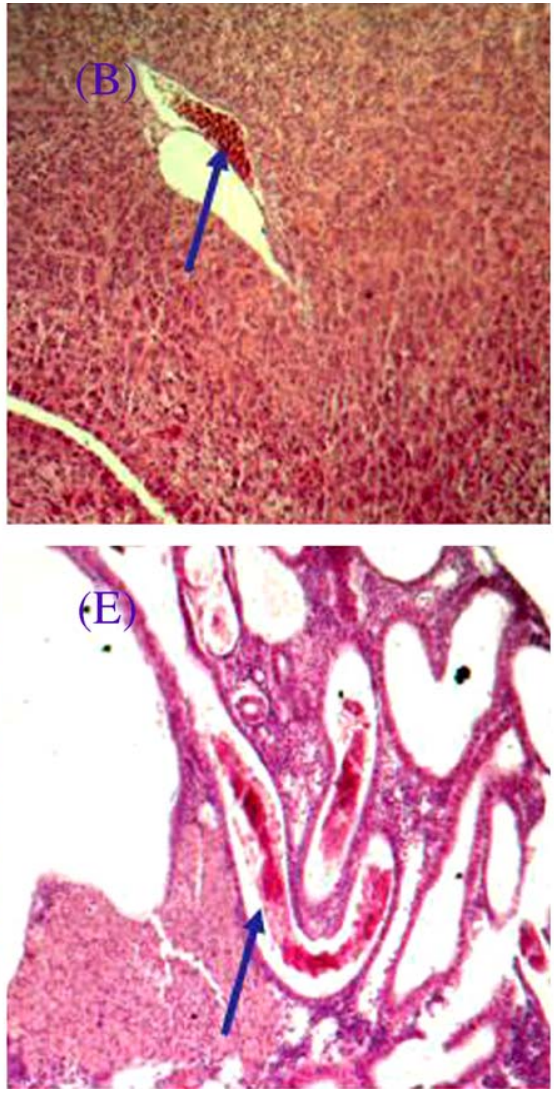
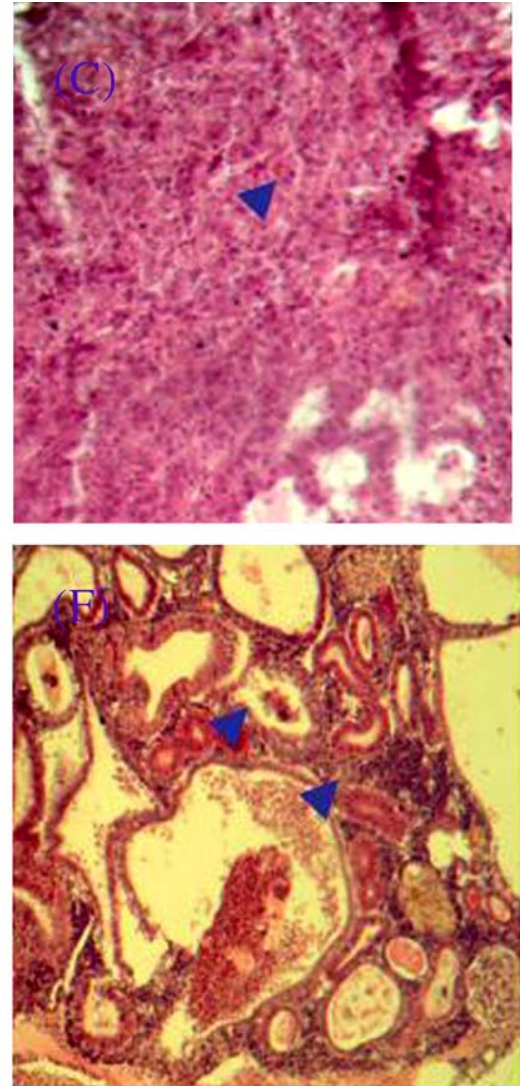

Fig. 4. Histological section of hepatic tissue and renal tissue of mature male medaka $(400 \times)$, stained with hematoxylin and eosin. (A) Hepatic tissue of a control male in PCP exposure experiment. (B) Hepatic tissue of a male exposure to $50 \mu \mathrm{g} / \mathrm{l} \mathrm{PCP}$, arrow showing accumulated eosinophilic material. (C) Hepatic tissue of a male exposure to $200 \mu \mathrm{g} / 1$ PCP, arrowhead showing swelling of hepatocytes. (D) Renal tissue of a control male in PCP exposure experiment. (E) Renal tissue of a male exposure to $100 \mu \mathrm{g} / \mathrm{l} \mathrm{PCP}$, arrow showing accumulated eosinophilic material. (F) Renal tissue of a male exposure to $200 \mu \mathrm{g} / \mathrm{l} \mathrm{PCP}$, arrowhead showing necrotic of epithelia. 


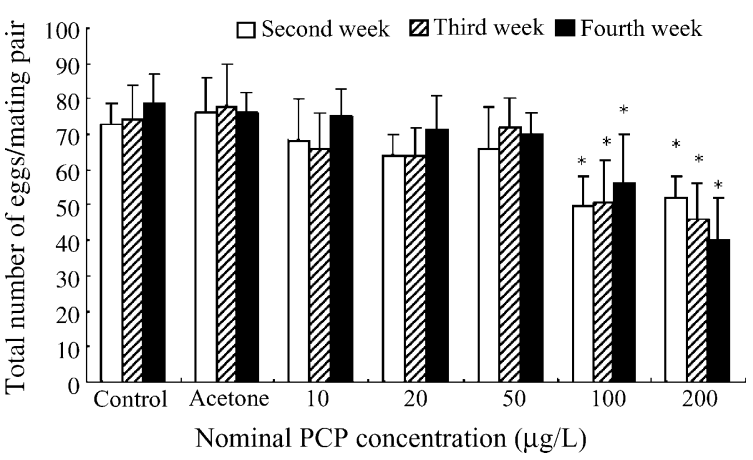

Fig. 5. Weekly changes (second, third and fourth weeks) of fecundity from mature medaka during 28-day PCP exposure period. * Significant differences from the values of the solvent controls or controls at $p<0.05$.

glomeruli and a system of tubules. However, in fish from the 100 and $200 \mu \mathrm{g} / \mathrm{l} \mathrm{PCP}$ treatments, incidences of kidney tissue lesions of male medaka from the 50 , 100 and $200 \mu \mathrm{g} / \mathrm{l}$ PCP treatments were $41.7 \%, 50 \%$ and $80 \%$, respectively (Table 3 ). We observed eosinophilic material accumulating in the sinusoids of the head kidney from fish in the 50 and $100 \mu \mathrm{g} / \mathrm{l} \mathrm{PCP}$ treatments (Fig. 4E). After treated with 100 and $200 \mu \mathrm{g} / \mathrm{l} \mathrm{PCP}$, lesions of kidneys were characterized by severe haemorrhage within the kidney tubules, the Bowman's space and the renal interstitium (Fig. 4E). Distinct changes of the tubular epithelia could be observed, including hypertrophy, degeneration and necrosis of epithelia (Fig. 4F). Accumulation of eosinophilic material was reported in kidneys of flounder injected with $10 \mathrm{mg} / \mathrm{kg}$ E2 [38]. These results suggest that PCP may target the liver and kidney. Whether elevations in VTG are contributing to the lesions is unclear from this study, has been observed in other fish such as fathead minnow (Pimephales promelas) [35] and zebrafish (Danio rerio) [40].

\subsection{Reproduction}

\subsubsection{Fecundity, fertility and sexual behavior}

During the first week of exposure, there was no significant reduction in total number of eggs in all PCP treatments, compared to controls (Data not shown). During the second, third and fourth week, a marked decrease in egg production was observed in fish from 100 and $200 \mu \mathrm{g} / \mathrm{l}$ PCP treatments $(p<0.05)$ (Fig. 5). Mean fertility in fish exposed to 100 and $200 \mu \mathrm{g} / \mathrm{l} \mathrm{PCP}$ was significantly decreased compared to controls during the third and fourth week of PCP exposure $(p<0.05)$ (Fig. 6). Significant decreases of the egg production and mean fertility of medaka were observed when exposed to endocrine disrupting chemicals including EE2 [41], 4-

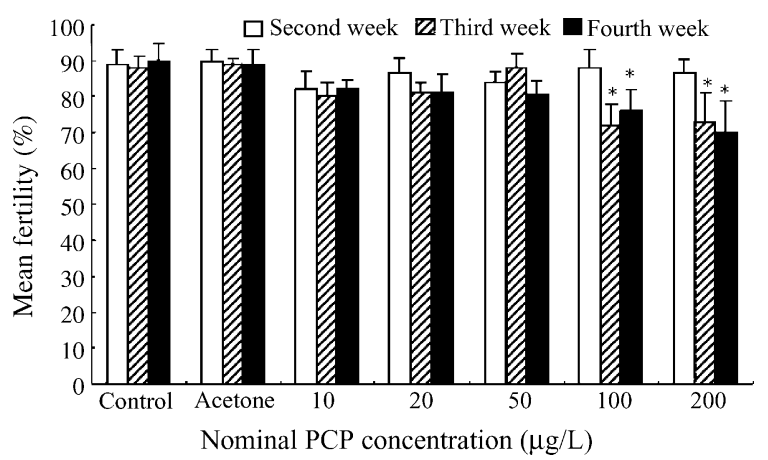

Fig. 6. Weekly changes (second, third and fourth weeks) of mean fertility of eggs from mature medaka during 28-day PCP exposure period. * Significant differences from the values of the solvent controls or controls at $p<0.05$.

NP and OP [14]. However, Ishibashi et al. [12] reported that egg production and mean fertility was not significantly diminished following exposure to $20-200 \mu \mathrm{g} / \mathrm{l}$ of TCS.

In this study, lesions of sexual behavior (following, dancing, floating, and crossing) of male medaka exposed to 100 and $200 \mu \mathrm{g} / \mathrm{l} \mathrm{PCP}$ were observed (data not to be shown). A number of studies have reported that endocrine disrupting chemicals such as E2 [42] and TBT [43] impaired their sexual behavior and decreased reproductive success. These authors suspected that an important reason for the reduction in the number of spawned eggs was likely to be abnormal sexual behavior.

\subsubsection{Hatching rates, time to hatching and sex ratio of F1 generation}

There was no significant reduction in hatching rates of embryos from medaka in all PCP exposure for 2-3 weeks, compared with that in the controls (Fig. 7).

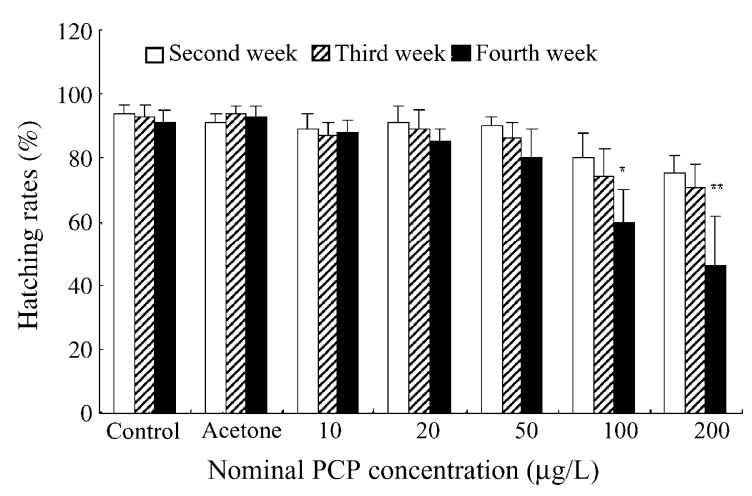

Fig. 7. Weekly changes (second, third and fourth weeks) of time to hatch of embryos from mature medaka during 28-day PCP exposure period. * Significant differences from the values of the solvent controls or controls at $p<0.05$. 


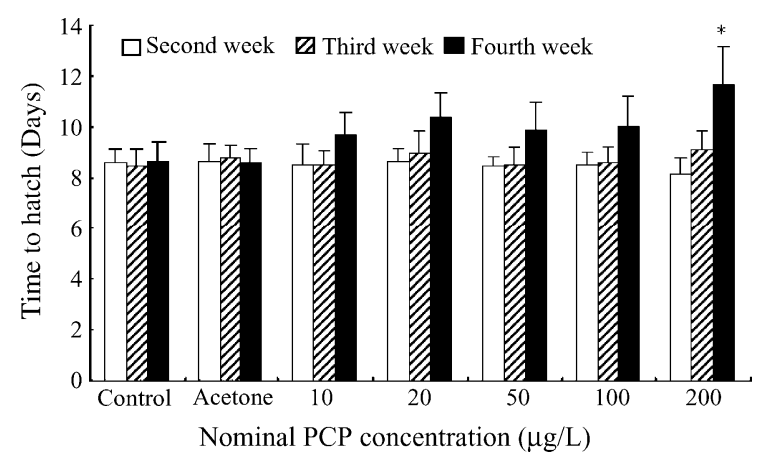

Fig. 8. Weekly changes (second, third and fourth weeks) of hatching rates of embryos from mature medaka during 28-day PCP exposure period. * and $* *$ Significant differences from the values of the solvent controls or controls at $p<0.05$ and $p<0.01$, respectively.

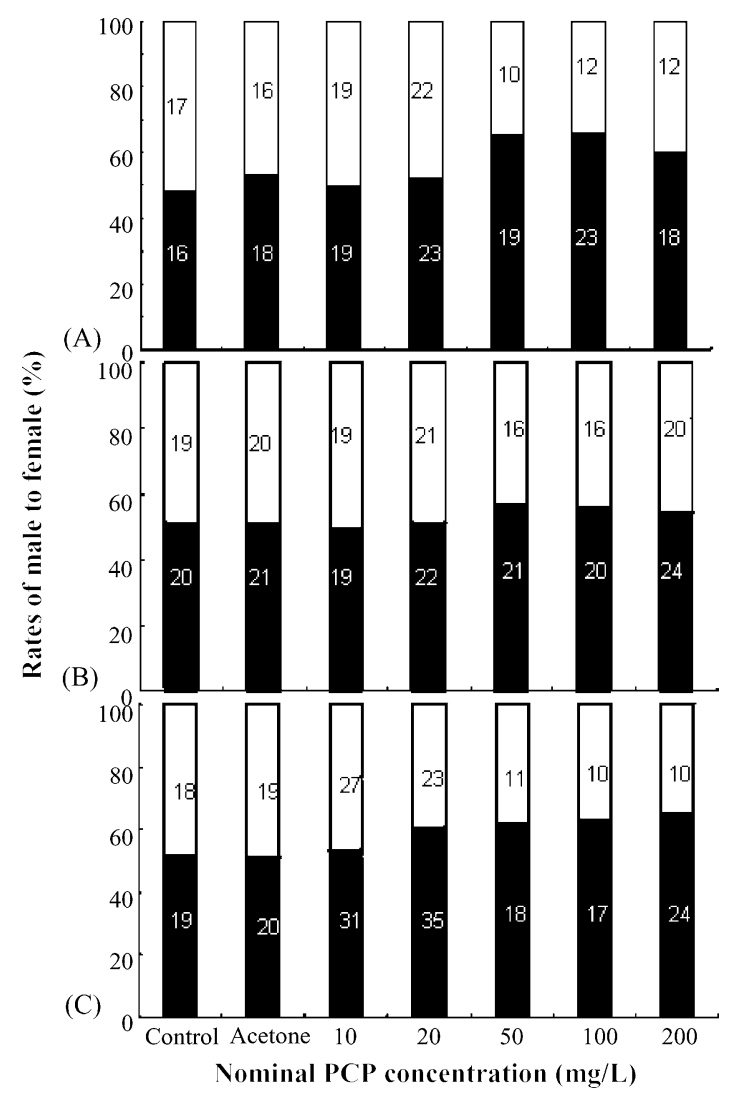

Fig. 9. Changes of ratios of males to females of offspring from mature medaka during 28-day PCP exposure period, open and solid bars represent male and female, respectively. (A) Ratios of males to females of offspring from mature medaka exposure to PCP at 14th day. (B) Ratios of males to females of offspring from mature medaka exposure to PCP at 21st day. (C) Ratios of males to females of offspring from mature medaka exposure to PCP at 28th day.
Hatching rates of embryos from medaka in 100 and $200 \mu \mathrm{g} / \mathrm{l} \mathrm{PCP}$ treatments after 4 weeks were significantly less than that of controls $(p<0.05)$ (Fig. 7). However, time to hatch of embryos from mature medaka in all treatments after 4 weeks increased, compared with that in the control group (Fig. 8). Time to hatch of embryos of medaka exposed to $200 \mu \mathrm{g} / \mathrm{l} \mathrm{PCP}$ treatment after 4 weeks was significantly higher than that from the control group $(p<0.05)$ (Fig. 8). When adult medaka exposed to $20 \mu \mathrm{g} / \mathrm{l}$ of TCS, hatching rates of the offspring (F1) decreased significantly [12]. In addition, hatching rates and time to hatch of offspring of medaka exposure to androgen methyltestosterone was significantly less than that of the control [44].

In F1 generations of PCP exposure fish, no cumulative mortality could be observed when the offspring was maintained in clean water for 60 days. In addition, body weight and body length of offspring were not significantly different from the control group (Data not shown). The female offspring (F1) from the 50 and $100 \mu \mathrm{g} / \mathrm{l}$ treatments were more than the male, but differences was not statistically significant (Fig. 9). Sex alternation was found in many types of fish including medaka after exposure to estrogen (E2) [10], EE2 [11] and 4-NP [45]. But sex ratios of offspring from medaka exposed to TCS [12] and EE2 [11] did not show significant changes. Our results support observations that there were no heritable characteristics of estrogenic/androgenic exposure in the offspring.

\section{Conclusion}

Plasma VTG levels of male medaka and EROD activities in liver microsomes of female medaka following PCP treatment were significantly induced. At the same time, the testis-ova of male medaka treated with 50 and $100 \mu \mathrm{g} / \mathrm{l} \mathrm{PCP}$ was observed as well as lesions in hepatic and renal tissue. PCP had adverse effects on reproduction including a reduction of egg production and mean fertility and sexual behavior. In the F1 generation, hatching rates and time to hatch of offspring were significantly affected in the $200 \mu \mathrm{g} / \mathrm{l} \mathrm{PCP}$ treatment. Therefore, our results suggest that PCP displays ER and AhR activity, induces tissue lesions and impairs reproduction in fish exposed to environmentally relevant concentrations.

\section{Acknowledgements}

This work was supported by National Basic Research Program of China (2003CB415005), National Natural Science Foundation of China (20337020) and Chinese Academy of Science (KZCX3-SW-431). 


\section{References}

[1] I.S. Thakur, P.K. Verma, K.C. Upadhaya, Involvement of plasmid in degradation of pentachlorophenol by Pseudomonas sp. from a chemostat, Biochem. Biophys. Res. Co. 286 (2001) 109-113.

[2] M.H. Zheng, B. Zhang, Z.C. Bao, H. Yang, X.B. Xu, Analysis of pentachlorophenol from water, sediments, and fish bile of Dongting Lake in China, Bull. Environ. Contam. Toxicol. 64 (2000) 16-19.

[3] WHO, Environmental Health Criteria 71: Pentachlorophenol, World Health Organization, Geneva, 1987.

[4] T. Kondo, H. Yamamoto, N. Tatarazako, K. Kawabe, M. Koshio, N. Hirai, M. Morita, Bioconcentration factor of relatively low concentrations of chlorophenols in Japanese medaka, Chemosphere 61 (2005) 1299-1304.

[5] E.C. Weinbach, Biochemical basis for the toxicity of pentachlorophenol, Proc. Natl. Acad. Sci. U.S.A. 43 (1957) 393-397.

[6] D.L. McCarthy, A.A. Claude, S.D. Copley, In vivo levels of chlorinated hydroquinones in a pentachlorophenol-degrading bacterium, Appl. Environ. Microbiol. 63 (1997) 1883-1888.

[7] T. Kishino, K. Kobayashi, Relation between toxicity and accumulation of chlorophenols at various $\mathrm{pH}$ and their absorption mechanism in fish, Water Res. 29 (1995) 431-442.

[8] T. Suzuki, K. Ide, M. Ishida, Response of MCF-7 human breast cancer cells to some binary mixtures of oestrogenic compounds in vitro, J. Pharm. Pharmacol. 53 (2001) 1549-1554.

[9] J. Jung, K. Ishida, T. Nishihara, Anti-estrogenic activity of fifty chemicals evaluated by in vitro assays, Life Sci. 74 (2004) 3065-3074.

[10] S. Scholz, H.O. Gutzeit, 17-Alpha-ethinylestradiol affects reproduction, sexual differentiation and aromatase gene expression of the medaka (Oryzias latipes), Aquat. Toxicol. 50 (2000) 363-373.

[11] C.D. Metcalfe, T.L. Metcalfe, Y. Kiparissis, G. Brenda, C. Khan, R.J. Hughes, T.R. Croley, R. March, T. Potter, Estrogenic potency of chemicals detected in sewage treatment plant effluents as determined by in vivo assays with Japanese medaka (Oryzias latipes), Environ. Toxicol. Chem. 20 (2001) 297-308.

[12] H. Ishibashi, N. Matsumura, M. Hirano, M. Matsuoka, H. Shiratsuchi, Y. Ishibashi, Y. Takao, K. Arizono, Effects of trisclosan on the early life stages and reproduction of medaka Oryzias latipes and induction of hepatic vitellogenin, Aquat. Toxicol. 67 (2004) 167-179.

[13] M.E. Hahn, T.M. Lamb, M.E. Schultz, R.M. Smolowitz, J.J. Stegeman, Cytochrome P4501A induction and inhibition by $3,3^{\prime}, 4,4^{\prime}$-tetrachlorobiphenyl in an Ah receptor-containing fish hepatoma cell line (PLHC-1), Aquat. Toxicol. 26 (1993) 185208.

[14] M. Skei, H. Yokota, M. Maeda, H. Tadokoro, K. Kobayashi, Effects of 4-nonylphenol and 4-tert-octylphenol on sex differentiation and vitellogenin induction in medaka (Oryzias latipes), Environ. Toxicol. Chem 22 (2003) 1507-1516.

[15] D.B. Van, R. Verheyen, H. Witters, Effects of 17a-ethinylestradiol in partial life-cycle test with zebrafish (Danio rerio): effects on growth, gonads and female reproductive success, Sci. Total Environ. 309 (2003) 127-137.

[16] S. Kitamura, Y. Shimizu, Y. Shiraga, M. Yoshida, K. Sugihara, S. Ohta, Reductive metabolism of $p, p^{\prime}$-DDT and $o, p^{\prime}$-DDT by rat liver cytochrome, Druge Metab. Dispos. 30 (2002) 113-118.

[17] C.W. Chen, C. Hurd, D.P. Vorojeikina, S.F. Aenold, A.C. Notides, Transcriptional activation of human estrogen receptor by DDT isomers and metabolites in yeast and MCF-7 cells, Pharmacology 53 (1997) 1161-1172.
[18] C.M. Foran, B.N. Peterson, W.H. Benson, Influence of parental and development cadmium exposure on endocrine and reproductive function in Japanese medaka (Oryzias latipes), Comp. Biochem. Physiol. C: Toxicol. Pharmacol. 133 (2002) 345354.

[19] S.C. Tilton, C.M. Foran, W.H. Benson, Relationship between ethinylestradiol -mediated changes in endocrine function and reproductive impairment in Japanese medaka (Oryzias latipes), Environ. Toxicol. Chem. 24 (2005) 352-359.

[20] M. Inudo, H. Ishibashi, N. Matsumura, M. Matsuoka, T. Mori, S. Taniyama, K. Kadokami, M. Koga, R. Shinohara, T.H. Hutchinson, T. Iguchi, K. Arizono, Effect of estrogenic activity, and phytoestrogen and organochlorine pesticide contents in an experimental fish diet on reproduction and hepatic vitellogenin production in medaka (Oryzias latipes), Comp. Med. 54 (2004) 673-680.

[21] T. Ma, X. Wan, Q. Huang, Z. Wang, J. Liu, Biomarker responses and reproductive toxicity of the effluent from a Chinese large sewage treatment plant in Japanese medaka (Oryzias latipes), Chemosphere 59 (2005) 281-288.

[22] G.T. Ankley, K.M. Jensen, M.D. Kahl, J.J. Korte, E.A. Makynen, Description and evaluation of a short-term reproduction test with the fathead minnow (Pimephales promelas), Environ. Toxicol. Chem. 20 (2001) 1267-1290.

[23] M. Dubois, H. Plaisance, J.P. Thome, Hierarchical cluster analysis of environmental pollutants through P450 induction in cultured hepatic cells, Ecotoxicol. Environ. Safety 34 (1996) 205-215.

[24] J.P. Barque, A. Abahamid, J.P. Flinois, P. Beaune, J. Bonaly, Constitutive over expression of immunoidentical forms of PCPinduced Euglena gracilis CYP-450, Biochem. Biophys. Res. Commun. 298 (2002) 277-281.

[25] S. Orn, P.L. Andersson, L. Forlin, M. Tysklind, L. Norrgren, The impact on reproduction of an orally administered mixture of selected PCBs in zebrafish (Danio rerio), Arch. Environ. Contam. Toxicol. 35 (1998) 52-57.

[26] E. Agradi, R. Baga, F. Cillo, S. Ceradini, H. Heltai, Environmental contaminants and biochemical response in eel exposed to Po river water, Chemosphere 41 (2000) 1555-1562.

[27] R. Van der Oost, S.C.C. Lopes, H. Komen, K. Satumalay, R. van den Bos, H. Heida, N.P.E. Vermeulen, Assessment of environmental quality and inland water pollution using biomarker responses in caged carp (Cyprinus carpio); use of a ioactivation: detoxication ratio as biotransformation index (BTI), Mar. Environ. Pollut. 46 (1998) 315-319.

[28] D.K.J. Jung, T. Klaus, K. Fent, Cytochrome P450 induction by nitrated polycyclic aromatic hydrocarbons, azarenes, and binary mixtures in fish hepatoma cell line PLHC-1, Environ. Toxicol. Chem. 20 (2001) 149-159.

[29] M. McArdle, A. Elskus, A. McElroy, B. Larsen, W. Benson, D. Schlenk, Estrogenic and CYP1A response of mummichogs and sunshine bass to sewage effluent, Mar. Environ. Res. 50 (2000) 175-179.

[30] D. Schlenk, D.M. Stresser, J.C. McCants, A.C. Nimrod, W.H. Benson, Influence of $\beta$-naphthoflavone and methoxychlor pretreatment on the biotransformation and estrogenic activity of methoxychlor in channel catfish (Ictalurus punctatus), Toxicol. Appl. Pharmacol. 145 (1997) 349-356.

[31] N. Egami, Production of testis-ova in adult males of Oryzias latipes. Effects on testis-ovum production of non-estrogenic steroids given singly or simultancously with estrodiol, Jpn. J. Zool. 11 (1955) 367-371.

[32] I.J. Kang, H. Yokota, Y. Oshima, Y. Tsuruda, T. Hano, M. Maeda, N. Imada, H. Tadokoro, T. Honjo, Effects of 4-nonylphenol on 
reproduction of Japanese medaka, Oryzias latipes, Environ. Toxicol. Chem. 22 (2003) 2438-2445.

[33] T.L. Metcalfe, C.D. Metcalfe, Y. Kiparissis, A.J. Niimi, C.M. Foran, W.H. Benson, Gonadal development and endocrine responses in Japanese medaka (Oryzias latipes) exposed to $o$, $p^{\prime}$-DDT in water or through maternal transfer, Environ. Toxicol. Chem. 19 (2000) 1893-1900.

[34] M.A. Gray, K.L. Teather, C.D. Metcalfe, Reproductive success and behavior of Japanese medaka (Oryzias latipes) exposed to 4tert-octylphenol, Environ. Toxicol. Chem. 18 (1999) 2587-2594.

[35] S. Pawlowski, R. van Aerle, C.R. Tyler, T. Braunbecka, Effects of 17a-ethinylestradiol in a fathead minnow (Pimephales promelas) gonadal recrudescence assay, Ecotoxicol. Environ. Safety 57 (2004) 330-345.

[36] D.M. Papoulias, D.B. Noltie, D.E. Tillitt, An in vivo model fish system to test chemical effects on sexual differentiation and development: exposure to ethinyl estradiol, Aquat. Toxicol. 48 (1999) 37-50.

[37] R.L. Herman, H.L. Kincaid, Pathological effects of orally administered estradiol to rainbow trout, Aquaculture 72 (1988) $165-172$.

[38] G. Zaroogian, G. Gardner, D. Borsay Horowitz, R. GutjahrGobell, R. Haebler, L. Mills, Effect of $17 \beta$-estradiol, $o, p^{\prime}$-DDT, octylphenol and $p, p^{\prime}$-DDE on gonadal development and liver and kidney pathology in juvenile male summer flounder (Paralochthys dentatus), Aquat. Toxicol. 54 (2001) 101-112.
[39] C.E. Purdom, P.A. Hardiman, V.J. Bye, N.C. Eno, C.R. Tyler, J.P. Sumpter, Estrogenic effects of effluents from sewage treatment works, Chem. Ecol. 8 (1994) 275-285.

[40] L.P. Weber, R.L. Hill Jr., D.M. Janz, Developmental estrogenic exposure in zebrafish (Danio rerio). II. Histological evaluation of gametogenesis and organ toxicity, Aquat. Toxicol. 63 (2003) 431-446.

[41] G.C. Blach, C.A. Mackenzie, C.D. Metcalfe, Alterations to gonadal development and reproductive success in Japanese medaka (Oryzias latipes) exposed to 17a-ethinylestradiol, Environ. Toxicol. Chem. 23 (2004) 782-791.

[42] Y. Oshima, I.J. Kang, M. Kobayashi, K. Nakayama, N. Imada, T. Honjo, Suppression of sexual behavior in male Japanese medaka (Oryzias latipes) exposed to 17beta-estradiol, Chemosphere 50 (2003) 429-436.

[43] K. Nakayama, Y. Oshima, T. Yamaguchi, Y. Tsuruda, I.J. Kang, M. Kobayashi, N. Imada, T. Honjo, Fertilization success and sexual behavior in male medaka, Oryzias latipes, exposed to tributyltin and its mixture with polychlorinated biphenyls, Environ. Toxicol. Chem. 24 (2005) 591-596.

[44] M. Skei, H. Yokota, H. Matsubara, M. Maeda, H. Tadokoro, Fish full life-cycle testing for androgen methyltestosterone on medaka (Oryzias latipes), Environ. Toxicol. Chem. 23 (2004) 774-781.

[45] Y. Hirofumi, S. Masanori, M. Masanobu, O. Yuji, T. Hiroshi, H. Tsuneo, K. Kunio, Life-cycle toxicity of 4-nonylphenol to medaka (Oryzias latipes), Environ. Toxicol. Chem. 20 (2001) 2552-2560. 